\title{
PENGARUH PENGGUNAAN LENSA DIVERGEN SERTA KONVERGEN TERHADAP DAYA KELUARAN PANEL SURYA
}

\author{
Amrul Mukmin ${ }^{1}$, Parjiman², Muhamad Rif'an ${ }^{3}$ \\ Pendidikan Teknik Elektro, Fakultas Teknik, Universitas Negeri Jakarta \\ ${ }^{1}$ E-mail: amrultdk@yahoo.com
}

\begin{abstract}
The purpose of this research is to increase the power output of the solar panels and to know the effect on the solar panel after adding a converging lens and a diverging treatment varying distances and angles. The hypothesis of this study is anticipated to the influence of the use of a diverging lens and converges to the power output of solar panels.

This study used an experimental method with quantitative approach. The subjects of the study were used that kind of Polycrystalline solar panels. Data analysis technique used is descriptive analysis with data collection techniques are observation laboratory and field observations.

The conclusion of this study is to raise the value of the output power on solar panels can use a converging lens. This is evidenced by the results of the testing are the biggest increase in the converging lens use solar panels to power 900 outputs the angle and the distance between the lens and solar panels with a power output of $25 \mathrm{~cm}$ measured $56.46 \mu \mathrm{W}$. The influence of the use of a converging lens located on the corner of 150 and the distance between the lens and the solar panel $21 \mathrm{~cm}$ with an increase of 203.64\%. These values occurred as a converging lens can focus the light so that the intensity of the light falling on the solar panels increases. While the greatest influence use of a diverging lens located on the corner of 300 and the distance between the lens and solar panels $1 \mathrm{~cm}$ with a decrease of $63.96 \%$. These values occurred as a diverging lens can refract light so that the intensity of the light falling on the solar panel decreases.
\end{abstract}

Keywords: Lens Divergent, Convergent Lens, Solar Panels

\begin{abstract}
ABSTRAK
Tujuan penelitian ini yaitu untuk meningkatkan daya keluaran pada panel surya dan untuk mengetahui perbedaan pengaruh pada panel surya setelah ditambahkan lensa konvergen serta divergen dengan perlakuan jarak dan sudut yang bervariasi. Hipotesis penelitian ini yaitu diduga adanya pengaruh dari penggunaan lensa divergen dan konvergen terhadap daya keluaran panel surya.

Penelitian ini menggunakan metode eksperimen dengan pendekatan kuantitatif. Subyek penelitian yang digunakan yaitu panel surya jenis Polycrystalline. Teknik analisis data yang digunakan yaitu analisis deskriptif dengan teknik pengumpulan data yaitu observasi laboratorium dan observasi lapangan.

Kesimpulan dari penelitian ini yaitu Untuk menaikan nilai daya keluaran pada panel surya dapat menggunakan lensa konvergen. Hal ini dibuktikan dengan hasil pengujian terdapat kenaikan terbesar penggunaan lensa konvergen pada panel surya terhadap daya keluaran yaitu sudut $90^{\circ}$ dan jarak antara lensa dan panel surya $25 \mathrm{~cm}$ dengan daya keluaran yang terukur 56,46 $\mu$ W.Pengaruh terbesar penggunaan lensa konvergen terdapat pada sudut $15^{\circ}$ dan jarak antara lensa dan panel surya $21 \mathrm{~cm}$ dengan kenaikan sebesar 203,64\%. Nilai tersebut terjadi karena lensa konvergen dapat memusatkan cahaya sehingga intensitas cahaya yang jatuh pada panel surya meningkat. Sedangkan pengaruh terbesar penggunaan lensa divergen terdapat pada sudut $30^{\circ}$ dan jarak antara lensa dan panel surya $1 \mathrm{~cm}$ dengan penurunan sebesar $63,96 \%$. Nilai tersebut terjadi karena lensa divergen dapat membiaskan cahaya sehingga intensitas cahaya yang jatuh pada panel surya menurun.
\end{abstract}

Kata kunci : Lensa Divergen, Lensa Konvergen, Panel Surya

\section{PENDAHULUAN}

Menurut Kamus Besar Bahasa Indonesia (KBBI), Energi adalah kemampuan untuk melakukan kerja (misalnya untuk energi listrik dan mekanika), daya (kekuatan) yang dapat digunakan untuk melakukan berbagai proses kegiatan, misalnya dapat merupakan bagian suatu bahan atau tidak terikat pada bahan (seperti sinar matahari) ${ }^{[7]}$. Berdasarkan penjelasan tersebut, dapat didefinisikan yaitu energi merupakan suatu bentuk yang dapat digunakan makhluk hidup untuk melakukan sesuatu dalam kegiatan seharihari.

Salah satu bentuk energi yang dimanfaatkan oleh manusia yaitu energi potensial. Energi potensial dimanfaatkan oleh manusia untuk membangkitkan energi listrik. Energi potensial merupakan transformasi dari beberapa energi, misalnya pada pemangkit energi listrik tenaga gas, manusia menggunakan gas alam sebagai 
penggerak turbin generator listrik. Turbin ini digerakan terus menerus sehingga dapat menghasilkan energi listrik. Gas yang digunakan merupakan gas alam yang diperoleh dengan pertambangan gas alam. Gas tersebut tidak langsung digunakan setelah diambil dari dasar bumi melainkan harus diproses dan dinaikan tekanannya menggunakan mesin sehingga tekanannya menjadi lebih tinggi dari sebelumnya. Ketika tekanan mencapai titik tertentu, maka gas tersebut dapat menggerakkan turbin generator secara berkelanjutan. Hal ini dilakukan terus menerus sampai cadangan gas diperoleh dari bumi habis.

Gas alam yang memiliki metana sebagai bahan utamanya merupakan sumber energi yang sangat bersih dan praktis ${ }^{[4]}$. Gas alam merupakan salah satu hasil kekayaan alam yang tidak dapat diperbaharui. Meskipun kini jumlahnya sangat melimpah, namun tidak menutup kemungkinan jika suatu saat energi tersebut akan habis. Energi listrik bukan merupakan satu-satunya energi yang harus dibangkitkan menggunakan energi alam seperti gas alam. Jika digunakan terus menerus untuk membangkitkan energi listrik, bisa saja energi tersebut habis dan generasi selanjutnya tidak dapat menikmatinya.

Bentuk pemanfaatan energi untuk menghasilkan energi listrik selain melalui energi gerak, dapat digunakan juga energi matahari. Energi matahari merupakan salah satu energi yang dapat diperbaharui. Selain itu, energi matahari juga sangat ramah terhadap lingkungan. Salah satu pembuktiannya yaitu sumber tersebut tidak akan menghasilkan polusi udara, air, daratan, maupun termal ${ }^{[4]}$. Energi matahari juga sangat aman digunakan karena matahari sebagai sumber utamanya merupakan sumber energi yang tersedia untuk semua orang. Dengan energi ini, setiap individu tidak akan lagi bergantung pada energi lain yang sangat rentan dimonopoli oleh sistem pemerintahan dan negara akan bebas dari embargo energi.

Pemanfaatan energi matahari perlu menggunakan suatu alat khusus yang dapat merubah energi matahari menjadi energi listrik. Alat khusus tersebut biasa disebut sel surya atau photovoltaik. sel surya atau photovoltaik merupakan sebuah semikonduktor yang memiliki permukaan luas dan terdiri dari rangkaian dioda tipe $\mathrm{p}$ dan $\mathrm{n}$ yang mampu merubah energi sinar surya menjadi energi listrik ${ }^{[5]}$. Benda tersebut dapat mengubah energi cahaya dari matahari menjadi energi listrik dengan sistem seperti pergerakan atom dalam alat tersebut. Cara ini dirasa lebih baik dan lebih ramah lingkungan dibanding penggunaan generator listrik untuk menghasilkan energi listrik. Hal tersebut dikarenakan pada generator memiliki polusi dan kebisingan yang dapat merusak alam serta mengganggu kehidupan manusia.

Bentuk pemanfaatan energi cahaya menjadi energi listrik masih dirasa sangat kurang dibandingkan dengan energi gerak. Hal ini dikarenakan sangat kecilnya efisiensi panel surya untuk membangkitkan energi listrik. Namun dari segi bahan bakarnya, pemanfaatan energi cahaya matahari sangat baik dikarenakan sumbernya yang akan terus ada sepanjang kehidupan. Oleh karena itu, perlu dilakukan penelitian lebih lanjut untuk mengembangkan panel surya menjadi lebih baik lagi agar masyarakat dapat meninggalkan cara lama dalam pembangkitan energi listrik menggunakan energi gerak.

Seiring berkembangnya ilmu pengetahuan, manusia menemukan lensa yang dapat memanipulasi datangnya cahaya sehingga dapat membiaskan atau memfokuskan cahaya matahari. Lensa yang dapat digunakan tersebut salah satunya yaitu lensa divergen dan konvergen. Mahasiswa Jurusan Fisika Fakultas Sains dan Teknologi Universitas Islam Negeri Maliki Malang bernama Faslucky Afifudin dan Farid Samsu Hananto telah melakukan penelitian yang berjudul "Optimalisasi Tegangan Keluaran Dari Solar Cell Menggunakan Lensa Pemfokus Cahaya Matahari”. Pada penelitian ini mereka menggunakan lensa konvergen sebagai pemfokus cahaya matahari dan digunakan terhadap panel surya jenis Policrystal dan Amorphous. Hasil penelitian mereka yaitu lensa konvergen mempengaruhi besarnya daya dari cahaya yang digunakan, sehingga intensitas dan energi cahaya meningkat dan mempengaruhi nilai tegangan keluaran dan arus listrik dari Solar Cell. Untuk Solar Cell jenis Policrystal efisiensi dapat ditingkatkan sampai $35.08 \%$ dan untuk Solar 
Cell jenis Amorphous dapatditingkatkansampai $31.77 \%^{[1]}$.

Berdasarkan hasil penelitian yang dilakukan oleh Faslucky Afifudin dan Farid Samsu Hananto, terdapat pengaruh terhadap Solar Cell ketika ditambahkan lensa konvergen sebagai pemfokus cahaya. Namun penelitian mereka belum menjelaskan secara detail mengapa menggunakan lensa konvergen saja. Hal ini dirasa perlu diteliti lebih lanjut dan dibandingkan dengan lensa lain salah satunya lensa divergen. Apakah lensa konvergen dan divergen memiliki pengaruh yang sama terhadap tegangan keluaran pada panel surya atau pengaruh yang diberikan berbeda antara lensa tersebut. Oleh karena itu, penelitian lebih lanjut perlu dilakukan untuk mengetahui pengaruh antara lensa konvergen dan lensa divergen terhadap panel surya.

Berdasarkan identifikasi masalah, dapat dibatasi permasalahan yang akan dibahas yaitu pengaruh penggunaan lensa divergen dan konvergen terhadap daya keluaran pada panel surya.

Berdasarkan pembatasan masalah, dapat dirumuskan permasalahan yang akan dibahas adalah bagaimanakah pengaruh penggunaan lensa divergen serta konvergen terhadap daya keluaran pada panel surya?

Berdasarkan rumusan masalah, tujuan penelitian ini akan berpusat yaitu :

1. Untuk meningkatkan daya keluaran pada panel surya.

2. Untuk mengetahui perbedaan pengaruh pada panel surya setelah ditambahkan lensa konvergen serta divergen dengan perlakuan jarak dan sudut yang bervariasi.

\section{METODE}

Tempat yang akan digunakan untuk penelitian yaitu lingkungan sekitar atap Gedung L Teknik Elektro Fakultas Teknik Universitas Negeri Jakarta. Tempat tersebut dipilih sebagai tempat penelitian karena tempat tersebut memiliki ruang yang cukup, jauh dari keramaian orang-orang dan mendapat cahaya matahari yang cukup guna menunjang penelitian. Penelitian akan berlangsung selama 4 bulan yaitu mulai dari bulan April 2016 sampai bulan Juli 2016. Subjek penelitian yang akan dibahas yaitu panel surya jenis Polycrystalline.
Metode penelitian yang digunakan yaitu menggunakan metode eksperimen dengan pendekatan kuantitatif. penelitian eksperimen merupakan penelitian yang memberikan pengaruh kepada variabel bebas yang diteliti menggunakan variabel terikat. Metode ini digunakan karena pada penelitian ini memberikan pengaruh kepada panel surya jenis Polycrystalline dengan lensa konvergen dan divergen. Menggunakan pendekatan kuantitatif karena penelitian ini hanya menguji pengaruh antara panel surya dengan lensa. Pengaruh yang dicari yaitu nilai daya keluaran panel surya ketika digunakan hal tersebut. Perlakuan yang diberikan yaitu jarak dan sudut sinar datang dengan dua situasi yaitu ruang tertutup dan ruang terbuka.

\section{a. Situasi Di Ruang Tertutup}

1. Menguji panel surya jenis Polycrystalline dengan sumber cahaya tanpa menggunakan lensa konvergen dan divergen.

2. Menguji panel surya jenis Polycrystalline dengan sumber cahaya menggunakan lensa divergen. Variasi yang dipakai yaitu variasi jarak mulai dari $10 \mathrm{~cm}, 20 \mathrm{~cm}, 30 \mathrm{~cm}, 40 \mathrm{~cm}$, $50 \mathrm{~cm}$ dan $60 \mathrm{~cm}$. Selain itu menggunakan variasi sudut sinar datang ke panel surya mulai dari $15^{\circ}, 30^{\circ}, 45^{\circ}, 60^{\circ}, 75^{\circ}$ dan $90^{\circ}$.

3. Menguji panel surya jenis Polycrystalline dengan sumber cahaya menggunakan lensa konvergen. Variasi yang dipakai yaitu variasi jarak lensa ke panel surya mulai dari $10 \mathrm{~cm}, 20 \mathrm{~cm}, 30 \mathrm{~cm}, 40 \mathrm{~cm}, 50 \mathrm{~cm}$ dan $60 \mathrm{~cm}$. Selain itu menggunakan variasi sudut sinar datang ke panel surya mulai dari $15^{\circ}, 30^{\circ}$, $45^{0}, 60^{\circ}, 75^{0}$ dan $90^{\circ}$.

\section{b. Situasi Di Ruang Terbuka}

1. Setelah melakukan pengujian di ruang tertutup maka akan didapat hasil pengujian yaitu daya tertinggi pada sudut dan jarak tertentu untuk situasi ruang tertutup.

2. Menggunakan hasil pengujian di ruang tertutup untuk melakukan pengujian di ruang terbuka. Jadi pada pengujian ruang terbuka merupakan pembuktian dari pengujian ruang tertutup dengan menggunakan perlakuan sudut yang sama namun, dibantu dengan alat bantu (gambar 1). 
3. Pengukuran yang dilakukan dengan kontrol waktu. Jadi pengujian dilakukan mulai jam 09.00 sampai 14.00 dengan alat bantu pengujian yaitu seperti gambar 1. Waktu tersebut merupakan lamanya waktu pengujian bukan perlakuan pada pengujian. Jadi, pengujian tetap menggunakan jarak dan variasi sudut seperti pengujian ruang tertutup untuk membuktikan hasil pengujian.

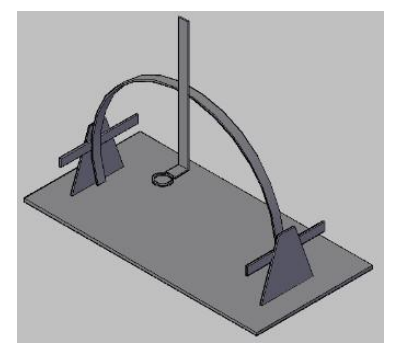

Gambar 1. Desain alat bantu pengujian di ruang terbuka

Gambar 1 merupakan desain alat bantu untuk pengujian di ruang terbuka. Alat tersebut menggunakan sistem otomatis dengan Arduino UNO Rev 3. Sistem yang dibuat pada alat tersebut yaitu seperti pada gambar 2. Alat tersebut menggunakan Arduino UNO Rev 3 dengan program yang diterjemahkan berdasarkan flow chart di atas.

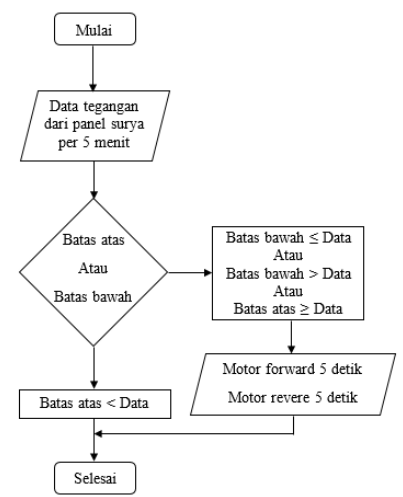

Gambar 2. Flow chart alat bantu pengujian

\section{Perlakuan Penelitian}

Penelitian ini menggunakan 2 situasi penelitian. Situasi pertama yaitu situasi di ruang tertutup dan situasi kedua di ruang terbuka. Situasi kedua dapat dilakukan jika situasi pertama telah selesai. Jika situasi pertama belum selesai maka situasi kedua tidak dapat dilakukan. Setiap situasi dibagi menjadi 3 tahap pengujian yaitu tahap pengujian tanpa lensa, tahap pengujian dengan lensa dan tahap pembandingan. Tahap pengujian tanpa lensa yaitu kegiatan penelitian yang menguji sampel tanpa variabel terikat yaitu lensa konvergen dan divergen. Tahap pengujian dengan lensa yaitu kegiatan penelitian dengan menggunakan variabel terikat yaitu lensa sebagai variabel pengarunya. Tahap ketiga yaitu tahap pembandingan. Tahap ini membandingkan antara penggunaan lensa konvergen, lensa divergen atau tanpa lensa yang lebih baik.

\section{Teknik Pengumpulan Data}

Teknik pengumpulan data yang digunakan pada penelitian ini yaitu observasi laboratorium dan observasi lapangan. Prosedur pengumpulan data menggunakan instrumen pengujian. Teknik ini digunakan karena pengujian ruang tertutup mengharuskan menggunakan tempat di dalam ruangan yang terhindar dari cahaya di luar cahaya yang digunakan saat pengujian. Oleh sebab itu, menggunakan observasi laboratorium karena dilakukan di dalam ruangan. Pada pengujian ruang terbuka harus dilakukan di tempat yang tersedia cahaya matahari penuh sehingga dilakukan di luar ruangan. Oleh sebab itu, menggunakan observasi lapangan karena dilakukan di luar ruangan.

\section{Teknik Analisis Data}

Teknik analisis yang digunakan yaitu analisis deskriptif dengan penarikan kesimpulan secara deskripsi menurut peneliti berdasarkan pada data-data hasil pengukuran observasi penelitian.

\section{HASIL DAN PEMBAHASAN}

Pada penelitian ini digunakan 2 kondisi pengujian yaitu pengujian di ruang tertutup dan pengujian di ruang terbuka. Pengujian di ruang tertutup dilakukan agar mencegah variabel lain selain variabel penelitian masuk ke proses penelitian. Di ruang tertutup dilakukan pengujian menggunakan sumber cahaya dengan daya 40 watt (lampu pijar). Cahaya ini diarahkan ke panel surya dengan jarak $90 \mathrm{~cm}$. Saat penelitian digunakan 2 variabe kontrol yaitu dengan variasi jarak antara lensa dengan panel surya dan sudut sinar datang.

Pengelompokan hasil pengujian akan menunjukan pengaruh yang diberikan oleh lensa divergen dan konvergen. Gambar 3 menunjukan 
diagram garis dari perbedaan sudut dengan jarak dapat mempengaruhi daya keluaran yang terukur menggunakan lensa divergen.

Tabel 1. Daya maksimal dari pengujian ruang tertutup

\begin{tabular}{ccccc}
\hline No & Jenis Pengujian & Jarak & $\begin{array}{c}\text { Sudut } \\
\text { Dava }\end{array}$ & Dava \\
\hline 1 & Tanpa Lensa & - & $90^{\circ}$ & $53,34 \mu \mathrm{W}$ \\
2 & Lensa Divergen & $1 \mathrm{~cm}$ & $90^{\circ}$ & $41,69 \mu \mathrm{W}$ \\
3 & Lensa Konvergen & $25 \mathrm{~cm}$ & $90^{\circ}$ & $56,46 \mu \mathrm{W}$ \\
\hline
\end{tabular}

Gambar 3 menunjukan daya keluaran tertinggi yang terukur ada pada jarak $10 \mathrm{~cm}$. Oleh sebab itu, dilakukan penelitian kembali diantara jarak $10 \mathrm{~cm}$ untuk mengetahui jarak yang dapat menghasikan daya keluaran lebih dalam jarak 10 $\mathrm{cm}$. Setelah dilakukan pengujian, diketahui jarak lain dalam jarak $10 \mathrm{~cm}$ yang dapat menghasilkan daya keluaran lebih besar yaitu jarak $1 \mathrm{~cm}$ antara lensa dan panel surya dalam pengujian ruang tertutup. Tabel 1 menunjukan daya keluaran yang terukur dengan jarak $1 \mathrm{~cm}$.

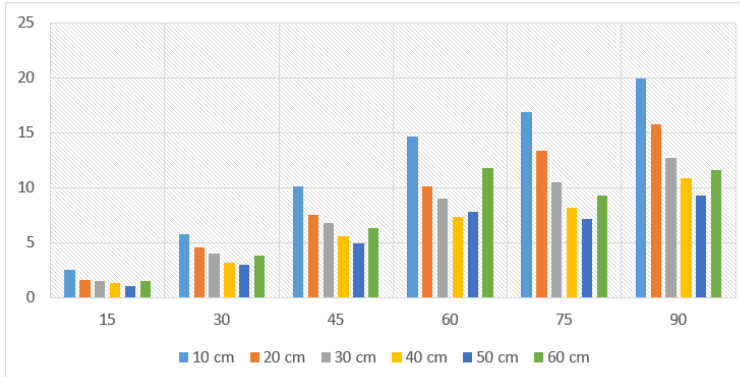

Gambar 3. Pengaruh sudut dan jarak terhadap daya keluaran menggunakan lensa divergen

Berdasarkan tabel 1 dapat diketahui bahwa pengaruh terbesar penggunaan lensa divergen pada panel surya terhadap daya keluaran yaitu pada sudut $90^{\circ}$ dan jarak antara lensa dan panel surya $1 \mathrm{~cm}$ dengan daya keluaran yang terukur 41,69 $\mu \mathrm{W}$. Hal dijadikan standar pada pengujian ruang terbuka. Hasil pengujian ruang terbuka dapat dilihat pada tabel 6. Selain itu, untuk pengaruh penggunaan lensa konvergen terhadap daya keluaran panel surya dapat dilihat pada gambar 4. Pada gambar ini terlihat kenaikan dan penurunan ketika menggunakan sudut serta jarak yang bervariasi.
Tabel 2. Daya keluaran dengan jarak $1 \mathrm{~cm}$

\begin{tabular}{ccc}
\hline No. & $\begin{array}{c}\text { Sudut Sinar } \\
\text { Datang }\end{array}$ & $\begin{array}{c}\text { Dava Keluaran } \\
\text { Terukur }\end{array}$ \\
\hline 1 & $15^{\circ}$ & $3,82 \mu \mathrm{W}$ \\
2 & $30^{\circ}$ & $7,94 \mu \mathrm{W}$ \\
3 & $45^{\circ}$ & $15,88 \mu \mathrm{W}$ \\
4 & $60^{\circ}$ & $25,94 \mu \mathrm{W}$ \\
5 & $75^{\circ}$ & $31,05 \mu \mathrm{W}$ \\
6 & $90^{\circ}$ & $41,69 \mu \mathrm{W}$ \\
\hline
\end{tabular}

Gambar 3 menunjukan daya keluaran tertinggi yang terukur ada pada jarak yang bervariasi yaitu $20 \mathrm{~cm}$ pada sudut $15^{\circ}, 30^{\circ}, 45^{\circ}$ dan $60^{\circ}$ serta 30 $\mathrm{cm}$ pada sudut $75^{\circ}$ dan $60 \mathrm{~cm}$ pada sudut $90^{\circ}$. Oleh sebab itu, dilakukan penelitian kembali diantara jarak $20 \mathrm{~cm}, 30 \mathrm{~cm}$ dan $60 \mathrm{~cm}$ untuk mengetahui jarak yang dapat menghasikan daya keluaran lebih. Setelah dilakukan pengujian, diketahui jarak lain dalam jarak $20 \mathrm{~cm}, 30 \mathrm{~cm}$ dan $60 \mathrm{~cm}$ yang dapat menghasilkan daya keluaran lebih besar yaitu jarak $21 \mathrm{~cm}$ dengan sudut $15^{0}, 18 \mathrm{~cm}$ dengan sudut $45^{\circ}, 23 \mathrm{~cm}$ pada sudut $60^{\circ}, 24 \mathrm{~cm}$ dengan sudut $75^{\circ}$ dan $25 \mathrm{~cm}$ dengan sudut $90^{\circ}$. Tabel 3 menunjukan daya keluaran yang terukur dengan jarak dan sudut tersebut.

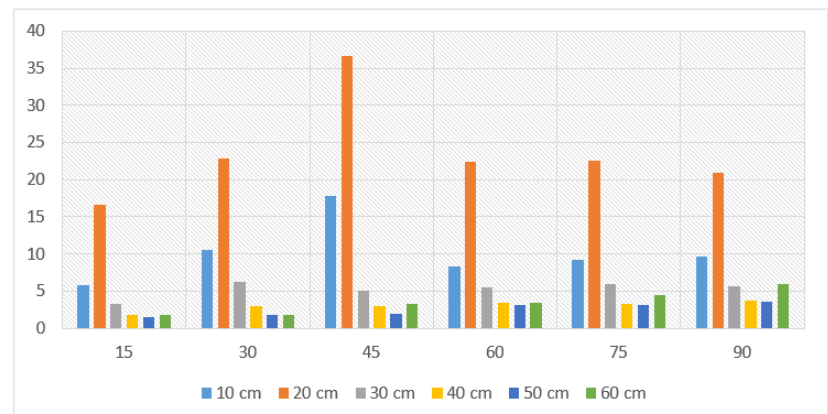

Gambar 4. Pengaruh sudut dan jarak terhadap daya keluaran menggunakanlensa konvergen

Tabel 3. Daya keluaran dengan jarak dan sudut tertentu

\begin{tabular}{cccc}
\hline No. & Sudut Sinar Datang & Jarak Lensa & Dava Terukur \\
\hline 1 & $15^{\circ}$ & $21 \mathrm{~cm}$ & $18,37 \mu \mathrm{W}$ \\
2 & $30^{\circ}$ & $20 \mathrm{~cm}$ & $22,89 \mu \mathrm{W}$ \\
3 & $45^{\circ}$ & $18 \mathrm{~cm}$ & $37,38 \mu \mathrm{W}$ \\
4 & $60^{\circ}$ & $23 \mathrm{~cm}$ & $24,29 \mu \mathrm{W}$ \\
5 & $75^{\circ}$ & $24 \mathrm{~cm}$ & $29,09 \mu \mathrm{W}$ \\
6 & $90^{\circ}$ & $25 \mathrm{~cm}$ & $56,46 \mu \mathrm{W}$ \\
\hline
\end{tabular}

Setelah didapat hasil penelitian, selanjutnya dibandingkan antara lensa konvergen dan lensa divergen. Tabel 4 merupakan perbandingan data 
hasil penelitian yang terjadi pada hasil pengujian. Tabel 5 merupakan hasil perbandingan dalam skala persen. Dengan tabel ini dapat dengan mudah diketahui perbandingan antara lensa divergen dan konvergen.

Tabel 4. Tabulasi data pengujian ruang tertutup

\begin{tabular}{ccccc}
\hline \multirow{2}{*}{ No. } & Sudut & Tanpa Lensa & Divergen & Konvergen \\
\cline { 3 - 5 } & $\left({ }^{\circ}\right)$ & Daya $(\mu \mathrm{W})$ & Daya $(\mu \mathrm{W})$ & Daya $(\mu \mathrm{W})$ \\
\hline 1 & 15 & 6,05 & 3,82 & 18,37 \\
2 & 30 & 22,03 & 7,94 & 22,89 \\
3 & 45 & 31,25 & 15,88 & 37,38 \\
4 & 60 & 30,68 & 25,94 & 24,29 \\
5 & 75 & 41,80 & 31,05 & 29,09 \\
6 & 90 & 53,34 & 41,69 & 56,46 \\
\hline
\end{tabular}

Berdasarkan tabel 4 dapat diketahui bahwa kenaikan terbesar penggunaan lensa konvergen pada panel surya terhadap daya keluaran yaitu sudut $90^{\circ}$ dan jarak antara lensa dan panel surya $25 \mathrm{~cm}$ dengan daya keluaran yang terukur 56,46 $\mu \mathrm{W}$. Berdasarkan pada tabel 5, dapat diketahui pengaruh terbesar penggunaan lensa konvergen terdapat pada sudut $15^{\circ}$ dan jarak antara lensa dan panel surya $21 \mathrm{~cm}$ dengan kenaikan sebesar $203,64 \%$.

Tabel 5.Perbandingan pengujian ruang tertutup

\begin{tabular}{cccc}
\hline No. & Sudut & Divergen & Konvergen \\
\cline { 3 - 4 } & $(\%)$ & $\%$ & $\%$ \\
\hline 1 & 15 & $-36,86$ & 203,64 \\
2 & 30 & $-63,96$ & 3,90 \\
3 & 45 & $-49,18$ & 19,62 \\
4 & 60 & $-15,45$ & $-20,83$ \\
5 & 75 & $-25,72$ & $-30,41$ \\
6 & 90 & $-21,84$ & 5,85 \\
\hline
\end{tabular}

Berdasarkan tabel 4 juga dapat diketahui bahwa penurunan terkecil penggunaan lensa divergen pada panel surya terhadap daya keluaran yaitu sudut $90^{\circ}$ dan jarak antara lensa dan panel surya $1 \mathrm{~cm}$ dengan daya keluaran yang terukur $41,69 \mu \mathrm{W}$. Namun untuk pengaruh terbesar penggunaan lensa divergen terdapat pada sudut $30^{\circ}$ dan jarak antara lensa dan panel surya $1 \mathrm{~cm}$ dengan penurunan sebesar $63,96 \%$.

Berdasarkan hasil pengujian, diketahui bahwa jarak lensa ke panel surya sangat berpengaruh terhadap daya keluaran yang terukur. Selain itu sudut sinar datang juga berpengaruh terhadap daya keluaran yang terukur. Hal ini disebabkan karena lensa divergen dan konvergen dapat memanipulasi sinar yang melewatinya.
Berdasarkan hasil penelitian yang terdapat pada tabel 1, dengan daya keluaran tertinggi menggunakan sudut, jarak dan lensa tersebut dapat dilihat perbandingannya dengan daya keluaran tanpa lensa. Daya keluaran yang terukur dengan lensa konvergen lebih tinggi dari pada lensa divergen dan tanpa lensa. Tabel 1 juga menunjukan kenaikan daya keluaran yang terukur jika diubah dalam skala persen maka daya keluaran yang menggunakan lensa divergen mengalami penurunan sebesar $21,84 \%$ dan yang menggunakan lensa konvergen mengalami kenaikan 5,85\% dari pengujian tanpa lensa. Hal tersebut sangat jelas menggambarkan bahwa terdapat pengaruh saat tanpa lensa dengan saat menggunakan lensa divergen dan lensa konvergen.

Setelah melakukan pengujian di ruang tertutup, dilanjutkan dengan pengujian ruang terbuka menggunakan alat pengukuran yang disesuaikan dengan pergerakan matahari. Hasil yang terukur tidak jauh berbeda walau dalam kondisi yang bebeda. Lensa konvergen dan divergen mempengaruhi daya keluaran yang terukur. Pengujian di ruang terbuka dapat dilihat pada tabel 6. Dari tabel tersebut dapat dilihat daya keluaran maksimal yang terukur.

Tabel 6. Tabulasi data pengujian di ruang terbuka

\begin{tabular}{ccccc}
\hline \multirow{2}{*}{ No. } & $\begin{array}{c}\text { Sudut } \\
\left({ }^{\circ}\right)\end{array}$ & $\begin{array}{c}\text { Tanpa } \\
\text { Lensa }\end{array}$ & Divergen & Konvergen \\
\cline { 3 - 5 } & & Daya $(\mu \mathrm{W})$ & Daya $(\mu \mathrm{W})$ & Daya $(\mu \mathrm{W})$ \\
\hline 1 & 15 & 2,84 & 2,63 & 3,00 \\
2 & 30 & 3,23 & 3,16 & 3,44 \\
3 & 45 & 2,64 & 2,61 & 2,73 \\
4 & 60 & 3,30 & 3,22 & 3,42 \\
5 & 75 & 3,54 & 3,47 & 3,64 \\
6 & 90 & 3,44 & 3,37 & 3,53 \\
\hline
\end{tabular}

Tabel 7.Perbandingan pengujian ruang terbuka

\begin{tabular}{cccc}
\hline No. & $\begin{array}{c}\text { Sudut } \\
(\circ)\end{array}$ & Divergen & Konvergen \\
\cline { 3 - 4 } & \% & $\%$ \\
\hline 1 & 15 & $-7,39$ & 5,63 \\
2 & 30 & $-2,16$ & 6,50 \\
3 & 45 & -1.13 & 3,41 \\
4 & 60 & $-2,42$ & 3,64 \\
5 & 75 & $-1,97$ & 2,82 \\
6 & 90 & $-2,03$ & 2,62 \\
\hline
\end{tabular}

Berdasarkan tabel 5 dapat diperoleh analisis bahwa terdapat pengaruh pada pengujian di ruang terbuka. Setelah dilakukan pengujian 
diperoleh data pengujian lensa divergen dapat menurunkan nilai daya keluaran dan lensa konvergen dapat menaikan nilai daya keluaran dari nilai tanpa lensa. Hasil analisis terdapat pada tabel 6. Tabel ini merupakan hasil perbandingan antara pengujian tanpa lensa dengan lensa divergen dan tanpa lensa dengan lensa konvergen.

Hasil pengujian yang telah dilakukan menunjukan penurunan dan kenaikan nilai daya keluaran yang terukur. Setelah melakukan pengujian di ruang terbuka telah terbukti bahwa lensa divergen dan konvergen memberikan pengaruh terhadap daya keluaran panel surya. Nilai minus berarti lensa divergen mengalai penurunan daya keluaran.

Nilai tertinggi kenaikan terjadi pada sudut $75^{\circ}$ dan jarak $24 \mathrm{~cm}$ dengan lensa konvergen dengan nilai $3,64 \mathrm{~mW}$ sedangkan untuk penurunan tertinggi terjadi pada sudut $45^{\circ}$ dengan jarak $1 \mathrm{~cm}$ dengan lensa divergen dengan nilai $2,61 \mathrm{~mW}$. Hal ini sangat berbeda dengan hasil pengujian pada ruang tertutup dengan hasil tertinggi pada sudut $30^{\circ}$ dan jarak $25 \mathrm{~cm}$ dengan lensa konvergen dan penurunan tertinggi pada lensa divergen pada sudut $15^{0}$ dengan jarak $1 \mathrm{~cm}$.

Pada pengujian ruang terbuka diperoleh data tertinggi pengaruhnya terhadap panel surya yaitu terdapat pada sudut $75^{\circ}$ dengan nilai pengaruh $6,50 \%$ dengan lensa konvergen dan penurunan $2,16 \%$ dengan lensa divergen. Berdasarkan 2 pengujian dengan ruang yang berbeda dapat diperoleh hasil penelitian yaitu lensa divergen dan konvergen berpengaruh terhadap daya keluaran yang terukur. Penggunaan lensa mempengaruhi intensitas cahaya yang melewatinya. Selain itu, intensitas cahaya mempengaruhi daya keluaran yang terukur. Oleh sebab itu, jika intensitas cahaya dimanipulasi dengan lensa divergen dan konvergen maka akan mempengaruhi daya keluaran yang terukur.

Pada pengujian ruang tertutup dapat diketahui perbedaan daya keluaran yang terukur antara tanpa lensa dengan yang menggunakan lensa divergen dan konvergen. Namun, pada pengujian ruang terbuka memiliki kesulitan yang berbeda. Jika pada ruang tertutup variabel selain variabel penelitian dapat dicegah masuk, maka pada ruang terbuka hal itu tidak dapat terjadi. Kesulitan pada ruang terbuka adalah memastikan cahaya matahari agar selalu sama intensitasnya dengan keadaan awal. Sehingga pada pengujian ruang terbuka dapat dilihat hasil pengujiannya berbeda-beda perhari bahkan perjam pengujian.

Berbeda dengan pengujian ruang tertutup yang intensitas cahayanya selalu sama bahkan dapat disesuaikan, maka pada pengujian ruang terbuka intensitas cahaya tidak dapat disesuaikan dan tidak dapat selalu sama. Berdasarkan hasil pengujian terdapat kelemahan pada ruang terbuka yaitu ketika cuaca mendung atau cahaya berada antara intensitas dibawah 25000 lux maka cahaya itu tidak dapat tembus ke lensa divergen dan konvergen. Saat keadaan tersebut lensa akan menjadi bayangan gelap dan terus bertambah gelap seiring dengan berkurangnya intensitas cahaya.

\section{KESIMPULAN DAN SARAN \\ Kesimpulan}

Berdasarkan hasil pengujian menggunakan lensa divergen dan lensa konvergen, dapat ditarik kesimpulan hasil penelitian yaitu :

1. Untuk menaikan nilai daya keluaran pada panel surya dapat menggunakan lensa konvergen. Hal ini dibuktikan dengan hasil pengujian terdapat kenaikan terbesar penggunaan lensa konvergen pada panel surya terhadap daya keluaran yaitu sudut $90^{\circ}$ dan jarak antara lensa dan panel surya $25 \mathrm{~cm}$ dengan daya keluaran yang terukur 56,46 $\mu \mathrm{W}$.

2. Pengaruh terbesar penggunaan lensa konvergen terdapat pada sudut $15^{0}$ dan jarak antara lensa dan panel surya $21 \mathrm{~cm}$ dengan kenaikan sebesar 203,64\%. Nilai tersebut terjadi karena lensa konvergen dapat memusatkan cahaya sehingga intensitas cahaya yang jatuh pada panel surya meningkat. Sedangkan pengaruh terbesar penggunaan lensa divergen terdapat pada sudut $30^{\circ}$ dan jarak antara lensa dan panel surya $1 \mathrm{~cm}$ dengan penurunan sebesar 63,96\%. Nilai tersebut terjadi karena lensa divergen dapat membiaskan cahaya sehingga intensitas cahaya yang jatuh pada panel surya menurun. 


\section{Saran}

1. Saran secara teoritis

Penelitian ini butuh pengembangan lebih baik lagi karena masih banyak kekurangan baik dari segi akurasi maupun dari segi desain. Untuk akurasi masih belum baik karena alat ukur yang dibutuhkan belm tersedia semuanya sehingga harus mencari di tempat-tempat lain untuk mendapatkan alat ukurnya. Dari segi desain juga belum baik, desainnya masih butuh perbaikan lagi agar lebih efisien dan dapa digunakan diberbagai bidang dan situasi. Sesungguhnya peneliti masih dalam tahap belajar sehingga kesempurnaan yang sebenarnya masih sangat jauh untuk dicapai.

2. Saran secara praktis

Pihak-pihak yang dapat dijadikan sasaran untuk mengembangkan yaitu pihak universitas sebagai lembaga institusi pendidikan tertinggi, lembaga penelitian, pusat-pusat pengkajian energi terbarukan, kementerian yang mengurusi bagian energi dan masyarakat tentunya sebagai pusat konsumtif energi listrik.

\section{DAFTAR PUSTAKA}

Afifudin, F. \& Hananto, F. S. (2012). Optimalisasi Tegangan Keluaran dari Solar Cell Menggunakan Lensa Pemfokus Cahaya Matahari. Jurnal Neutrino, 4(2): 164-177.

Lechner, N. (2007). Heating, Cooling Lighting : Metode Desain untuk Arsitektur. Jakarta: PT Grafindo Persada.

M, Suyitno. (2011). Energi Alternatif. Surakarta: Yuma Pustaka.

Pauji, M. (2013).Pengembangan Alat Peraga Miniatur Konversi Energi Gerak menjadi Energi Listrik Sebagai Media Pembelajaran Fisika SMA/SMK di Jakarta.[Skripsi].Jakarta: Fakultas Matematika dan Ilmu Pengetahuan Alam, Universitas Negeri Jakarta.

Poerwadarminta, W.J. (1984). Kamus Besar Bahasa Indonesia. Jakarta: Balai Pustaka.
Sugiyono. (2014). Metode Penelitian Kombinasi (Mixed Metode). Bandung: Alfabeta 